\title{
Penentuan Aktifitas Spesifik Tirosinase dari Kentang Solanum tuberosum
}

\author{
Wuryanti, Damin Sumardjo, Haris Budiatna \\ Laboratorium Biokimia Jurusan Kimia FMIPA Undip
}

\begin{abstract}
Abstrak
Tirosinase dari umbi kentang (Solamum tuberosum) telah diisolasi secara fisik dan fraksinasi dilakukan dengan $\left(\mathrm{NH}_{4}\right)_{2} \mathrm{SO}_{4}$ menjadi $\mathrm{F}_{1}(0-10 \%), \mathrm{F}_{2}(10-20 \%), \mathrm{F}_{3}(20-30 \%)$ dan $\mathrm{F}_{4}(30-$ $60 \%$ ). Penentuan aktifitas enzim ini dengan menentukan serapan menggunakan spektrofotometer UV-Vis pada panjang gelombang $475 \mathrm{~nm}$, sedang kadar protein ditentukan dengan metode Lowry. Hasil penelitian menunjukkan bahwa aktifitas spesifik tirosinase dari kentang adalah sebagai berikut: Ekstrak kasar 4,293 u/mg, $\mathrm{F}_{1}(0-10 \%) 5,274 \mathrm{u} / \mathrm{mg}, \mathrm{F}_{2}(10-$ $20 \%) 5,579 \mathrm{u} / \mathrm{mg}, \mathrm{F}_{3}(20-30 \%) 5,583 \mathrm{u} / \mathrm{mg}$ dan $\mathrm{F}_{4}(30-60 \%) 5,827 \mathrm{u} / \mathrm{mg}$. Sebagai kesimpulan dari penelitian ini adalah bahwa fraksinasi dengan $\left(\mathrm{NH}_{4}\right)_{2} \mathrm{SO}_{4}$ dapat dicapai hingga tingkat kemurnian 1,357 terhadap ekstrak kasar dengan spesifik aktifitas 5,827 u/mg
\end{abstract}

Kata kunci: Tirosinase, aktifitas spesifik

\section{Determination of Spesific Activity of Tyrosinase Potato Solanum tuberosum}

\begin{abstract}
Isolation and fractionation of tyrosinase from potato (Solamum tuberosum) with $\left(\mathrm{NH}_{4}\right)_{2} \mathrm{SO}_{4}$ to $F_{1}(0-10 \%), F_{2}(10-20 \%), F_{3}(20-30 \%)$ and $F_{4}(30-60 \%)$ has been carried out. Determination of activity unit of tyrosinase was done by using spectrofotometer UV-Vis, wave length $475 \mathrm{~nm}$, while protein content was determined by Lowry methode. The resulted showed that crude extract has spesific activity $4,293 \mathrm{u} / \mathrm{mg}, \mathrm{F}_{1}(0-10 \%) 5.274 \mathrm{u} / \mathrm{mg}, \mathrm{F}_{2}(10-20 \%)$ $5.579 \mathrm{u} / \mathrm{mg}, \mathrm{F}_{3}(20-30 \%) 5.583 \mathrm{u} / \mathrm{mg}$ and $\mathrm{F}_{4}(30-60 \%) 5.827 \mathrm{u} / \mathrm{mg}$. It can be concluded that fractionation with $\left(\mathrm{NH}_{4}\right)_{2} \mathrm{SO}_{4}$ can be done to purity level 1.357 for crude extract with spesific activity $5.827 \mathrm{u} / \mathrm{mg}$.
\end{abstract}

Key-words: tyrosinase, specific activity

\section{PENDAHULUAN}

Enzim pada saat ini sudah banyak dimanfaatkan orang baik dibidang industri maupun ilmu pengetahuan. Enzim sebagai aditif dapat meningkatkan kualitas produk. Dalam industri pada deterjen berenzim misalnya, memiliki daya pembersih yang tinggi, demikian pula pada pasta gigi yang berenzim yang mampu mencegah sariawan dan dapat digunakan tanpa mengunakan air terlebih dahulu, atau dalam proses pengempukan daging dan lain-lain (1)

Selain sebagai bahan aditif pada produk, enzim juga dapat dimanfaatkan sebagai katalis pada pengolahan bahan-bahan tertentu menjadi produk., walaupun penanganan enzim lebih sulit dari pada katalis kimia biasa, karena lebih mudah rusak. Sekalipun demikian dalam kasus-kasus tertentu enzim lebih disukai karena kadang-kadang enzim merupakan alternatif yang ada, terutama untuk sel- 
sel hidup yang kerjanya spesifik dan tidak dapat melakukan perombakan bila tidak ada enzimnya.

Salah satu dari sekian banyak enzim yang terdapat pada tumbuhtumbuhan adalah tirosinase yang sering dikenal dengan nama katekolase atau polifenol oksidase.Tirosinase disebut juga polifenol oksidase atau fenolase (O - difenol : oksigen oksido reduktase E.C. 1. 1.03.1) atau terkadang disebut dengan fenolase, katekol oksidase, kresolase dan katekolase. Tetapi penamaan enzim ini dengan tirosinase lebih sering digunakan karena substrat yang digunakan adalah tirosin. ${ }^{(3)}$

Enzim ini cukup berperan dalam proses pencoklatan enzimatis dan juga mampu mengkatalisis senyawa fenol menjadi $\mathrm{O}$ - kuinon, sehingga dapat dijadikan sebagai alternatif penanganan limbah fenol.(3)

Dari sekian banyak jenis tumbuhan sebagai sumber enzim tirosinase, adalah jamur (mashroom) yang diduga memiliki kandungan tirosinase cukup besar, seperti halnya pada apel, pisang, kentang dan jenis tumbuhan lain yang mengalami pencoklatan karena konversi senyawa fenol menjadi melanin. Kentang (Solanum tuberosum) adalah tanaman iklim sedang atau sub tropik dan daerah tinggi $(1000-1500 \mathrm{~m})$. Tanaman kentang memiliki kandungan gizi $2 \%$ protein, $\quad 0,1 \%$ lemak dan 20,9\% karbohidrat dimana didalam protein diduga mengandung enzim tirosinase ${ }^{(7)}$

Satuan aktifitas unit enzim (U) yang paling umum dipakai adalah jumlah mikromol substrat yang diubah menjadi produk tiap menit. Satuan ini untuk menyatakan jumlah enzim seperti halnya massa atau satuan lainnya. Kadar enzim dinyatakan dalam satuan aktifitas enzim tiap satuan volume (U/volume). Nilai ini dipakai untuk menghitung jumlah mol enzim yang sebenarnya bila angka pergantian (ternover number) pada keadaan yang sama diketahui. Angka pergantian adalah jumlah dari reaksi yang di katalisis oleh satu molekul enzim tiap satuan waktu (menit atau detik). ${ }^{(4)}$

Dengan kata lain unit international (U) didefinisikan sebagai satu mikromol substrat yang dikonversikan menjadi produk per menit pada kondisi tertentu $\left(25^{\circ} \mathrm{C}\right.$ atau $30^{\circ} \mathrm{C}$ pada $\mathrm{pH}$ optimum), sedangkan aktifitas spesifik didefinisikan perbandingan antara total aktifitas unit dengan total kadar protein, ${ }^{(5)}$

Satu aktifitas unit tirosinase $=$ $1 \mu \mathrm{mol}$ substrat ( $\mathrm{L}$ - tirosin) yang dirubah menjadi produk (dopakrom) tiap menit. Dengan demikian

Aktifitas unit : Unit $/ \mathrm{ml}$.

Aktifitas spesifik : $\frac{\text { Unit } / m L}{m g / m L}=\frac{\text { Unit }}{m g}$

Total aktifitas $\quad$ (aktifitas spesifik)

$\mathrm{x}$ (Total mg protein). ${ }^{(6)}$

\section{METODOLOGI PENELITIAN}

\section{Sampel}

Kentang atau Solanum tuberosum didapat dari pasar. Penentuan aktifitas spesifik dengan metode spektrofotometri UV - Vis karena terbentuknya warna dari dopakrom.

Sampel kentang segar ditimbang sebanyak $500 \mathrm{~g}$ dan dibersihkan kemudian dimasukan ke dalam blender serta ditambah sedikit demi sedikit aseton sebanyak $300 \mathrm{~mL}$. Blender dihidupkan sehingga kentang halus dan homogen. Setelah homogen 
kemudian disaring untuk memisahkan ampas dengan larutan.

\section{Bahan}

Semua bahan yang digunakan, memiliki tingkat kemurnian p.a. (pro analisis) kecuali aquades, serum albumin dan $\mathrm{L}$ - tirosin.

\begin{abstract}
Alat
Spektrofotometer UV - Vis (Shimadzu - 1201), sentri fuga (centrific - 228); Blender (makita); membran selopan; p H meter (orion 420A); Neraca Analitik (kern 870); Magnetic stirrer (Quart); shakker (Ts $330 \mathrm{~A}$ ), termometer, termos es dan alatalat gelas untuk analisis.
\end{abstract}

\section{Eksperimen}

\section{Penyediaan Ekstrak Kasar}

Dari hasil preparasi tersebut diatas diperoleh ekstrak kasar enzim tirosinase lalu ditentukan unit aktifitas dan kadar proteinnya.

\section{Fraksinasi tirosinase}

Ekstrak kasar yang diperoleh difraksinasi (pengendapan bertingkat) dengan amunium sulfat dari $\mathrm{F}_{1}(0-10$ $\%), F_{2}(10-20 \%), F_{3}(20-30 \%)$ dan $\mathrm{F}_{4}(30-60 \%)$, kemudian diaduk selama 10 menit dengan menggunakan shakker pada $200 \mathrm{rpm}$. Setelah itu didiamkan sebentar lalu disaring, endapan yang didapat ditambah buffer fosfat dan didialisis selama 12 jam dengan buffer yang sama dan serapan dibaca pada panjang gelombang 280 $\mathrm{nm}$ dengan spektrofotometer UV - Vis.

\section{Uji aktifitas tirosinase}

$\begin{array}{cccc} & \text { Sebanyak } & 0,128 & \text { gram L- } \\ \text { tirosin } & \text { dilarutkan } & \text { dalam aquades }\end{array}$

sampai $100 \mathrm{ml}$, tiap $4 \mathrm{ml}$ larutan $\mathrm{L}$ tirosin ditambah sampel sebanyak $1 \mathrm{ml}$ dengan kontak waktu selama 5 menit, pada suhu $28^{\circ} \mathrm{C}$. Kemudian serapan diukur pada panjang gelombang 475 mm. Kemudian dihitung nilai aktifitas unitnya.

\section{Penentuan kadar protein.}

Sebanyak $0,6 \mathrm{~mL}$ supernatan ekstrak kasar dan hasil dialisis dengan kejenuhan $\left(\mathrm{NH}_{4}\right)_{2} \mathrm{SO}_{4} \mathrm{~F}_{1}(0-10 \%)$, $F_{2}(10-20 \%), F_{3}(20-30 \%)$ dan $\mathrm{F}_{4}(30-60 \%)$ ditambah $3 \mathrm{~mL}$ lowry $\mathrm{C}$ dan di inkubasi selama 20 menit pada suhu kamar. Kemudian ditambah 0,3 $\mathrm{mL}$ folin dengan cepat dan didiamkan selama 45 menit pada suhu kamar sambil dikocok. Serapan dibaca pada panjang gelombang $655 \mathrm{~nm}$.

\section{PEMBAHASAN}

Dari penelitian yang telah dilakukan, isolasi tirosinase dari kentang ternyatą setiap 500 gram kentang diperoleh sekitar 1 gram ekstrak kasar. Semakin banyak konsentrasi tirosinase dalam suatu bahan makanan, makin cepat proses pencoklatan berlangsung. Dari hasil penelitian menunjukkan konsentrasi tirosinase dari kentang dalam ekstrak kasar sedikit. Tirosinase merupakan enzim intra selular sehingga untuk mengisolasi harus dengan memecahkan dinding sel. Pemecahan dinding sel dapat dilakukan secara kimia misalnya dengan penambahan alkali dan dapat juga secara fisik misalnya dengan pembekuan, pemampatan dengan homogenizer, pencairan, penggilingan dengan pasir dan selain itu bisa dilakukan dengan penambahan enzim tertentu. Pada penelitian ini dilakukan pemecahan dinding sel secara fisik yaitu dengan diblender sampai 
homogen dengan menggunakan pelarut aseton yang dapat mengendapkan secara reversibel.

Pada umumnya metode pemurnian enzim tidak berbeda dengan prinsip untuk pemurnian protein, karena enzim mengandung protein. Metode tersebut salah satunya adalah dengan pengendapan / koagulasi.

Untuk mengendapkan tirosinase dari larutan supernatan digunakan $\left(\mathrm{NH}_{4}\right)_{2} \mathrm{SO}_{4}$ karena memiliki beberapa kelebihan diantaranya :

- $\left(\mathrm{NH}_{4}\right)_{2} \mathrm{SO}_{4}$ sebagai garam netral yang kelarutannya dalam air tinggi.

- $\left(\mathrm{NH}_{4}\right) 2 \mathrm{SO}_{4}$ dalam air tidak mengganggu fungsi dan bentuk enzim

Dalam penelitian disini dilakukan pengendapan $\mathrm{F}_{1}(0-10 \%)\left(\mathrm{NH}_{4 / 2}\right.$ $\mathrm{SO}_{4}, \mathrm{~F}_{2}(10-20 \%)\left(\mathrm{NH}_{4}\right)_{2} \mathrm{SO}_{4}, \mathrm{~F}_{3}($ $20-30 \%)\left(\mathrm{NH}_{4}\right)_{2} \mathrm{SO}_{4}, \mathrm{~F}_{4}(30-60 \%$ ) $\left(\mathrm{NH}_{4}\right) 2 \mathrm{SO}_{4}$ yang kemudian didialisis untuk memisahkan molekul-molekul besar dan molekul-molekul kecil dengan menggunakan membran semi permeabel slopan

Penambahan fraksi amo-nium sulfat didasarkan kepada tabel yang sudah tersedia (lamp 1 ) atau dengan menggunakan rumus penambahan : ${ }^{(9)}$

$$
g=\frac{533\left(\mathrm{~S}_{2}-\mathrm{S}_{1}\right)}{100-0,3 \mathrm{~S}_{2}}
$$

dimana

$\mathrm{S}_{2}=$ Prosentase larutan jenuh ke-2

$\mathrm{S}_{1}=$ Prosentase larutan jenuh ke-1

Untuk setiap penambahan garam amonium sulfat, harus diperhatikan volume .filtrat sebelumnya sehingga penambahan garam tersebut tidak berlebihan.
Dari data hasil penelitian menunjukkan bahwa nilai aktifitas spesifik untuk ekstrak kasar sebesar $4,293 \mathrm{u} / \mathrm{mg}$. Untuk hasil dialisis dengan penambahan amonium sulfat kristal .secara bertingkat, penambahan optimum untuk kentang pada $\mathrm{F}_{4}(30-$ $60 \%$ ) $\left(\mathrm{NH}_{4}\right)_{2} \mathrm{SO}_{4}$ dengan nilai 5,817 $\mathrm{u} / \mathrm{mg}$.

Selama proses dialisis suhu diatur sedemikian rupa sehingga dengan pengadukan menggunakan magnet stirrer yang berlangsung selama 12 jam tersebut, tidak menjadikan suhu semakin meningkat yang menimbulkan terjadinya dinaturasi protein. Untuk hal itu digunakan es dan garam dapur sebagai kondensor agar suhu tetap rendah.

Membran yang digunakan dalam dialisis adalah membran selopan (celloupan / kertas kaca) yang memiliki pori-pori sangat halus dan mampu memisahkan molekul-molekul besar dan molekul-molekul kecil pada proses pemurnian protein. Pemilihan .selopan sebagai membran dialisis dan tidak menggunakan membran yang lain didasarkan pada pertimbangan bahwa dialisis yang digunakan adalah buffer fosfat dan bukan larutan EDTA atau gliserol yang biasa digunakan untuk dialisis ion logam. Disamping itu pertimbangan yang lainnya karena selopan lebih murah dan mudah didapat dengan kwalitas cukup baik, bila dibandingkan dengan membran koloid dan selulosa

Untuk menentukan aktifitas spesifik, setelah ditentukan unit aktifitas, ditentukan pula kadar proteinnya sehingga perbandingan antara unit aktifitas dengan kadar protein merupakan nilai aktifitas spesifik. Penentuan unit aktifitas dan 
penentuan kadar protein dengan menggunakan spektrofotometer UV Vis untuk menentukan serapan warnanya. ${ }^{(10)}$

\section{KESIMPULAN}

Dari percobaan yang telah dilakukan dapat dikemukakan beberapa kesimpulan yaitu :

1. Tirosinase dapat diisolasi dari umbi kentang.

2. Sedikit konsentrasi tirosinase yang dapat di isolasi dari umbi kentang.

\section{Daftar Pustaka}

1. F. G. Winarno (1983), "Enzim Pangan", Edisi Pertama PT Gramedia, Jakarta, hal 40-46.

2. Kurnia Kusna widjaja (1983), "Biokimia", Edisi Pertama Penerbit Alumni, IKAPI, Bandung, hal. $123-124$.

3. Gerald Reed (1975), "Food Science and Technology A Series of Monografi', Edisi pertama, New York, hal. 236-237.

4. M. C. Gilvery Goldsterin (1990), "Biokimia Suatu Pendekatan Fungsional", Edisi ketiga,
Airlangga University press, hal $336-338$.

5. Keith Wilson (1989), "A Biologist Guide To Principle and Techniques of Practical Biochemistry", Edisi ketiga, New York, hal. $81-82$.

6. P. Tijssen (1985), "Practise and Theory of Enzyme immunoassay", El Sevier Science Publisher, Tokyo, hal $170-173$.

7. John M. Clark (1988), "Experimental Biochemistry", Edisi kedua, Freeman and Company, San Fransisco, hal 83 84.

8. Meity.Suradji (1991), "Jamur Merang dan Budi Dayanya", Edisi pertama, Penerbar Swadaya Press, Jakarta, hal. 8 - 15.

9. Robert K Scopes (1982), "Protein Purification Principles and Practice", edisi kedua, London, Paris, Tokyo, hal $230-231$.

10. Slamet Sudarmadji (1984), "Prosedur Analisa Untuk Analisa Bahan Makanan Dan Pertanian", Edisi ketiga, Penerbit Liberty, Yogyakarta. Hal $55-58$. 